\title{
ТЕХНІКА ВСТАНОВЛЕННЯ ЛАПАРОСКОПІЧНИХ ПОРТІВ ДЛЯ ВИКОНАННЯ СИМУЛЬТАННИХ ЛАПАРОСКОПІЧНИХ ОПЕРАЦІЙ
}

\section{Техніка встановлення лапароскопічних портів для виконання симультанних лапароскопічних операцій}

М. М. Галей

Тернопільський національний медичний університет імені І. Я. Горбачевського МОЗ України

КП «Волинська обласна клінічна лікарня»

Резюме. За даними офріційної статистики ВООЗ на даний момент у країнах західного світу до 30 \% усіх пацієнтів, які звертаються за медичною допомогою 3 приводу хірургічної патології органів черевної порожнини, мають супутню хірургічну патологію [1-3]. Також 3 огляду на курс медицини, скерований на максимальну ефрективність, рекомендують виконувати раннє хірургічне лікування таких патологій, як жовчнокам'яна хвороба, грижі стравохідного отвору діафррагми, грижі передньої черевної стінки.

Мета дослідження - оцінити ергономічну складову при виконанні звичайних лапароскопічних операцій та симультанних лапароскопічних операцій при лікуванні жовчнокам'яної хвороби (ЖКХ) та поєднаних хірургічних патологій, таких, як спайкова хвороба органів черевної порожнини (ОЧП), пахові грижі, грижі стравохідного отвору діафррагми (СОД), новоутворення підшлункової залози та печінки (доброякісні). Оцінити вплив ергономіки на основні показники ефективності й безпеки операцій. Вuзначити переваги і недоліки методик. Оцінити чи впливає розроблений метод на ергономіку під час операції.

Матеріали і методи. Остежено 175 пацієнтів, які перенесли операції для симультанного лікування супутнього й основного хірургічного захворювань на базі ВОКЛ ВІМДЛ. Аналізували та порівнювали показники операцій, такі, як тривалість доопераційного обстеження, тривалість операції, кількість інтраопераційних ускладнень, кількість ліжко-днів після операції, інтенсивність больового синдрому, частота ранніх післяопераційних ускладнень. Використано методику з нульовою гіпотезою, аналіз за Пірсоном, метод Манна - Уітні.

Результати. Виконання симультанного лапароскопічного втручання з використанням розробленої техніки позитивно впливає на час операції та кількість інтраопераційних ускладнень. Також помітний вплив на коморорт під час операції, що виражається через зменшення психоемоційної та фрізичної втоми у хірургів після операцій із використанням розробленої техніки, порівняно зі звичайною технікою, що дозволяє ви-
Technique of installing laparoscopic ports to perform simultaneous laparoscopic surgeries

M. M. Halei

I. Horbachevsky Ternopil National Medical University Volynian Regional Clinical Hospital

e-mail: galej.mm@gmail.com

Summary. According to official WHO statistics, currently in the Western world up to $30 \%$ of all patients who seek medical care for surgical pathology of the abdominal cavity have concomitant surgical pathology. Also, due to the course of medicine aimed at maximum efficiency, it is recommended to perform early surgical treatment of such pathologies as gallstones, hiatal hernia, hernia of the anterior abdominal wall.

The aim of the study - to evaluate the ergonomic component when performing conventional laparoscopic surgeries and simultaneous laparoscopic surgeries for the treatment of gallstone disease and combined surgical pathologies, such as hiatal hernia, inguinal hernias, peritoneal adhesions, pancreatic and liver tumors (benign); assess the impact of ergonomics on key performance and safety indicators; identify the advantages and disadvantages of methods; assess whether the developed method affects ergonomics during the surgery.

Materials and Methods. 175 patients underwent surgery for the simultaneous treatment of concomitant and major surgical diseases in Volynian Regional Clinical Hospital. Indicators of operations were analyzed and compared, such as duration of preoperative examination, duration of surgery, number of intraoperative complications, time of hospital stay after surgery, intensity of pain syndrome, frequency of early postoperative complications. The method with the null hypothesis, Pearson's analysis and Mann-Whitney method was used.

Results and Discussion. Performing simultaneous laparoscopic interventions using the developed technique has a positive effect on the time of surgery and the number of intraoperative complications. There is also a noticeable effect on comfort of surgeons during the surgery, which is expressed in the reduction of psycho-emotional and physical fatigue in surgeons after surgeries using the developed technique in comparison with conventional technique. The technique allows performing one-time treatment of cholecystolithiasis and 
конувати одномоментне лікування холецистолітіазу та супутньої хірургічної патології без погіршення ергономічних умов. Методика, розроблена на базі ВІМДЛ ВОКЛ, є ефрективною та безпечною.

Висновки. Рівень фрізичної та емоційної втоми прямо впливає на якість виконання операції, а також на проведення наступних операційних втручань, що відображається у статистичних даних рівня ускладнень та часу операцій, які суттєво знижуються після того, як ми впровадили техніку виконання симультанних операцій.

Ключові слова: ЖКХ; пахова грижа; КСОД; ергономіка; симультанні; лапароскопія.

\section{ВСТУП}

За даними офріційної статистики ВОО3, на даний момент у країнах західного світу до 30 \% усіх пацієнтів, які звертаються за медичною допомогою з приводу хірургічної патології органів черевної порожнини, мають супутню хірургічну патологію [1-3]. Також 3 огляду на курс медицини, скерований на максимальну ефрективність, рекомендують виконувати раннє хірургічне лікування таких патологій, як жовчнокам'яна хвороба, грижі стравохідного отвору діафрагми, грижі передньої черевної стінки [4]. Вимоги до раннього паралельного лікування пояснюються 3 декількох боків. По-перше, раннє лікування патології, виявленої у стадії ремісії, гарантує легший перебіг лікування як операційного, так і консервативного етапів, також меншими є ризики ускладнень під час лікування, наприклад для жовчнокам'яної хвороби доведений зв'язок між фрормою холециститу та ятрогенним ураженням загальної жовчної протоки [5-7]. По-друге, після лікування пацієнта виписують зі стаціонару 3 рекомендаціями планової госпіталізації, а потім із різних причин повертається уже із загостренням хвороби чи/та її ускладненнями [8]. По-третє, паралельне лікування гарантує максимальну економічну ефективність, так як потребує лише одноразової госпіталізації, меншого сумарного терміну перебування в умовах стаціонару, менше сумарних витрат часу та коштів на передопераційний, підготовчий, діагностичний етапи [9]. Тобто суттєво зростає потреба у виконанні симультанних операцій, а з огляду на те, що лапароскопічні операції стали стандартними для більшості хірургічних патологій, то особливої уваги заслуговують саме лапароскопічні техніки симультанних операцій. Наше дослідження спрямоване на огляд сучасних даних про сполучені хірургічні патології та їх одночасне лікування шляхом виконання симультанних операційних втручань із використанням різних технік встановлення портів, включаючи й розроблену нами, їх порівняння, що буде актуально для лікарів-хірургів.

Метою дослідження було оцінити ергономічну складову при виконанні звичайних лапароско- concomitant surgical pathology without deterioration of ergonomic conditions. Developed methodic is effective and safe.

Conclusions. The level of physical and emotional fatigue directly affects the quality of the surgery, as well as the subsequent surgical interventions, which is reflected in the statistics of complications and time of operations, which are significantly reduced after we have introduced the technique of simultaneous surgeries.

Key words: gallstones; inguinal hernia; hiatal hernia; ergonomics; simultaneous; laparoscopy.

пічних операцій та симультанних лапароскопічних операцій при лікуванні жовчнокам'яної хвороби (ЖКХ) та поєднаних хірургічних патологій, таких, як спайкова хвороба органів черевної порожнини (ОЧП), пахові грижі, грижі стравохідного отвору діафррагми (СОД), новоутворення підшлункової залози та печінки (доброякісні). Оцінити вплив ергономіки на основні показники ефективності й безпеки операцій. Визначити переваги і недоліки методик. Оцінити чи впливає розроблений метод на ергономіку під час операції.

\section{МАТЕРІАЛИ I МЕТОДИ}

Дослідження було виконане у формі оглядового ретроспективного аналізу. Для його проведення використано статистику, зроблену в умовах відділення інвазивних методів діагностики та лікування Волинської обласної клінічної лікарні (ВІМДЛ ВОКЛ). Пацієнти проходили хірургічне лапароскопічне лікування поєднаних хірургічних патологій із 2009 до 2019 рр. Хворих, яких відібрали для обстеження, було 175 (табл. 1)

Досліджували параметри есрективності та безпеки проведеного операційного лікування залежно від використання методу виконання симультанних лапароскопічних втручань. До 2012 р. застосовували стандартну техніку введення робочих портів. 32013 р. використовували лише власну розроблену техніку виконання симультанних лапароскопічних втручань.

У дослідженнях аналізували вік, стать, різновид і поєднання захворювань для оцінки однорід-

Таблиця 1. Структура нозологічних поєднань у обстежуваних пацієнтів

\begin{tabular}{l|c}
\hline \multicolumn{1}{c|}{ нозологічне поєднання } & $\begin{array}{c}\text { Кількість хворих, } \\
\mathrm{n}(\%)\end{array}$ \\
\hline ЖКХ+ грижа СОД & $61(34,8 \%)$ \\
\hline ЖКХ+ кіста печінки & $11(6,2 \%)$ \\
\hline ЖКХ+ кіста підшлункової залози & $5(2,9 \%)$ \\
\hline ЖКХ+ кіста нирок & $11(6,2 \%)$ \\
\hline ЖКХ+ спайкова хвороба ОчП & $56(32 \%)$ \\
\hline ЖКХ+ пахова грижа & $23(13,1 \%)$ \\
\hline ЖКХ+ двобічна пахова грижа & $8(4,8 \%)$ \\
\hline
\end{tabular}


ності груп, а також аналізували час операційного втручання та наркозу, операційна втрата крові, ускладнення, що викали під час і після операційного лікування, а також втома хірургів після виконаної операції для оцінки ефективності та безпеки методу виконання симультанних операцій. Для оцінки фрізичної втоми використовувався тест на стандартне м'язове зусилля. Для оцінки психоемоційної втоми застосовували тест Кітаока як найбільш оперативні й точні в інтерпретації, адже вимірювання відбувались до, після операції, у кінці робочого часу.

\section{РЕЗУЛЬТАТИ Й ОБГОВОРЕННЯ}

Виконання симультанних операцій $€$ значно більш доцільним, ніж багатоетапне лікування, чи відтермінування лікування патології, що не викликає в даний момент станів, що потребують екстренного лікування в даний момент. На наш погляд, найважливішим аспектом у лікуванні таких пацієнтів $\epsilon$ операційний етап. Тому саме операційне втручання має бути максимально ефективним і безпечним. Не останню роль у забезпеченні цього відіграє ергономіка операції, яка забезпечує максимальну візуалізацію робочого поля, максимальну ефективність робочих рухів та зручність для хірурга, що веде до скорочення робочого часу [10]. При зміні об'єму і перебігу операції, включення додаткового етапу $€$ можливість суттєвого зниження комфорту виконання операції, або появи необхідності введення додаткових портів для інструментів, що негативно відзначається на самопочутті пацієнта, його задоволення лікуванням, ризиках ускладнень, та в косметичному плані. Тому важливо виконувати симультанні лапароскопічні операції не як дві послідовні, а як одну велику, і розраховувати ергономіку операції з огляду на це. Правильна ергономіка роботи забезпечує зниження опору роботі хірурга, мінімалізацію помилок й точність рухів [11]. Статична робота, як відомо, є найвиснажливішою, а робота хірурга в операційній якраз і має високий статичний компонент [12]. Ергономіка - наука найкращого розміщення працівника (в нашому випадку хірурга) і встановлення максимально сприятливого оточення [13]. Для максимізації ефективності роботи хірургів на базі ВІМДЛ ВОКЛ було розроблено техніку встановлення портів, яка базується на власному досвіді й сумації розробок колег з інших країн, що, на нашу думку, є найбільш вдалими.

Основні правила:

1. Операційний стіл під час лапароскопічної операції має бути на висоті ледве зігнутих рук хірурга, а саме 64-77 см, залежно від зросту хірурга, що дозволяє виконувати максимальний діапазон рухів 3 мінімізацією нефрізіологічних навантажень [14].

2. Монітор повинен розміщуватись навпроти спеціаліста за принципом прямої лінії, на висоті, що відповідає 25-градусовому підйому очей хірурга над горизонтальним рівнем, для максимально вірного сприйняття рухів під час операції, та розвантаження спини та шиї [15].

3. Повинен виконуватись принцип «прямої лінії», тобто монітор, орган-мішень, очі хірурга мають бути розміщені співосно, для збереження сприйняття рухів [16].

4. Підйом і поворот кінця коаксіального напрямку роботи, для відведення суміжних органів до 25-40 градусів [17].

5. Порти повинні бути розміщені піднятими до площини з підвищенням в 30-45, і зі співвідношенням в 60-90 градусів [17].

6. Інструменти повинні розміщуватись зі збереженням правил, що дозволяють їх використовувати максимально ефективно. Порт для лапароскопа повинен бути введений у проекції білої лінії живота, щоб відстань від розрізу до органа-мішені складала $1 / 2$ довжини лапароскопа (рис. 1). Таке розміщення дозволить зберегти можливості для достатньої візуалізації, і маневру при виникненні такої необхідності та дозволить уникнути «фрехтування» лапароскопа з інструментами.

7. Порти повинні розміщуватись 3 підвищенням у 30-45 (рис. 2) відносно площини операційного стола, на якому зафріксовано пацієнта. Така

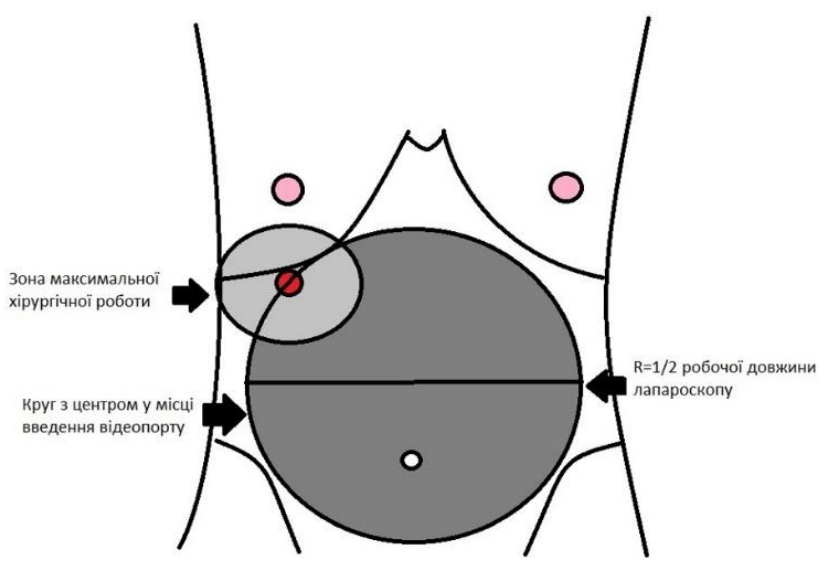

Рис. 1. Розміщення відеопорта, зважаючи на довжину лапароскопа.

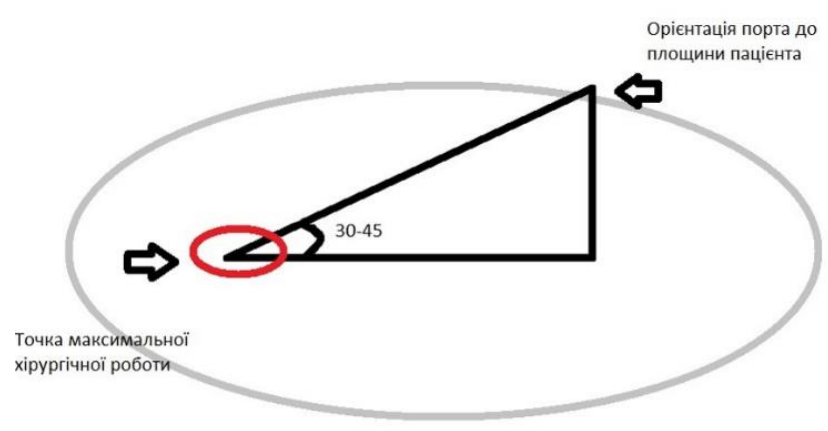

Рис. 2. Розміщення портів відносно площини операційного стола.
Вісник медичних і біологічних досліджень Bulletin of Medical and Biological Research 
орієнтація, разом з підйомом стола, дозволить виконувати рухи у зручній для хірурга площині, 3 мінімізацією опору м'язово-апоневротичного шару пацієнта під час операції.

8. Порти для робочих інструментів повинні розміщуватись під кутом у 60-90 (рис. 3) між собою для забезпечення максимальної ергономічності рухів, зі збереженням постави та зручного розведення рук хірурга.

Для виконання стандартних операцій вже відомі найзручніші та найефективніші моделі встановлення портів та розташування хірургів біля пацієнта, як-от модель «бейсбольного діаманта» і хірург ліворуч від пацієнта для холецистектомії, та півколо 3 європейським розміщенням хірурга між розведених ніг пацієнта. Для виконання симультанних операційних втручань ми розробили моделі встановлення портів, що максимально відповідають правилам ергономіки у виконанні лапароскопічних операцій, а також надають усіх потрібних можливостей для ефективного завершення операційного лікування (рис. 4-6).

Зрозуміло, що до досягнення певного досвіду ця інфрормація була недоступною, тому у ВІМДЛ до 2012 р. операції виконували з використанням стандартних моделей. При ретроспективному аналізі операційних протоколів можна чітко побачити, що середній час виконання операцій був суттєво більшим, а рівень інтраопераційних ускладнень вищим, ніж під час виконання тотожних маніпуляцій, використовуючи розроблену модель. Дані для порівняння представлені в таблицях 2-5.

За статистичними даними можна чітко простежити розвиток техніки операцій на базі ВІМДЛ. Використання нашої методики допомогло зменшити середній час операцій, рівень ускладнень та зменшити фрізичний та психоемоційний вплив на хірургів $(p<0,05)$. Ці показники легко пояснити тим, що наша методика забезпечує максимальну

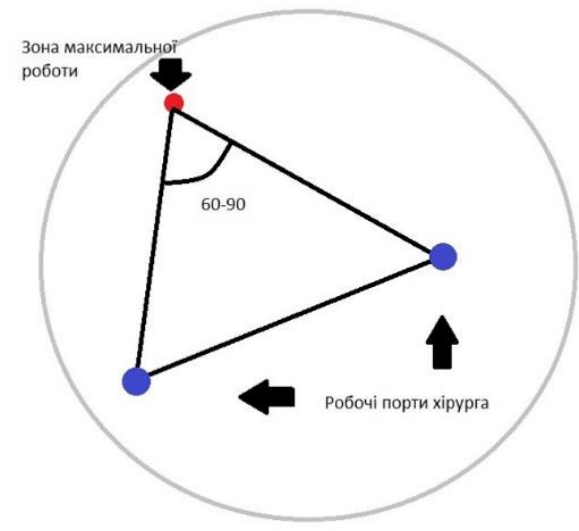

Рис. 3. Розміщення портів для робочих інструментів відносно органа-мішені та між собою.

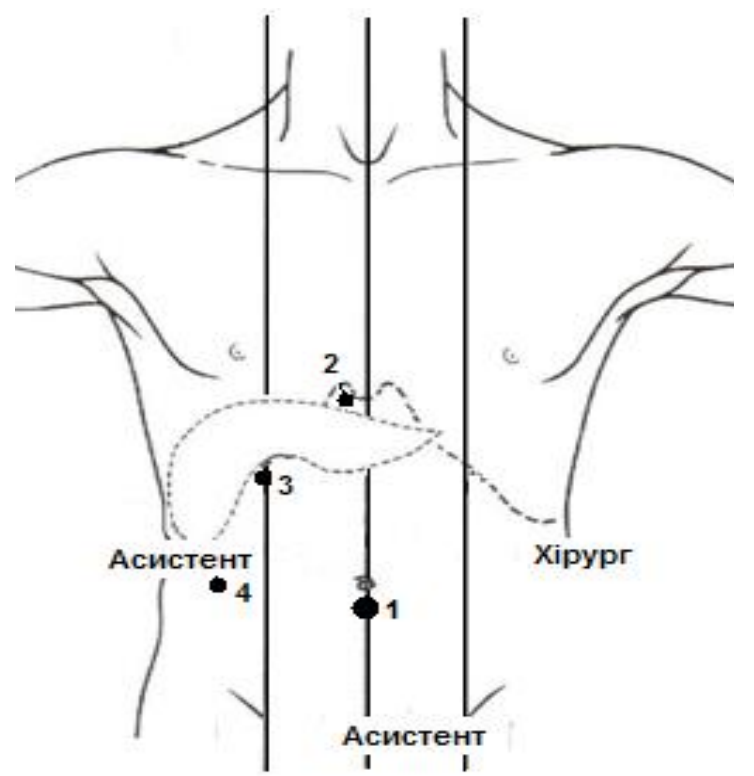

Рис. 4. Схема розміщення портів для виконання холецистектомії і холедохолітотомії з інтраопераційною холангіографрією: 1 - 10 мм порт для лапароскопа, 2 - 10 мм порт для основного інструмента хірурга та затискача для холангіографії, 3 - 5 мм порт для додаткового інструмента хірурга, 4 - 5 мм порт для додаткового інструмента асистента. Холецистектомію виконують як завершальний етап.

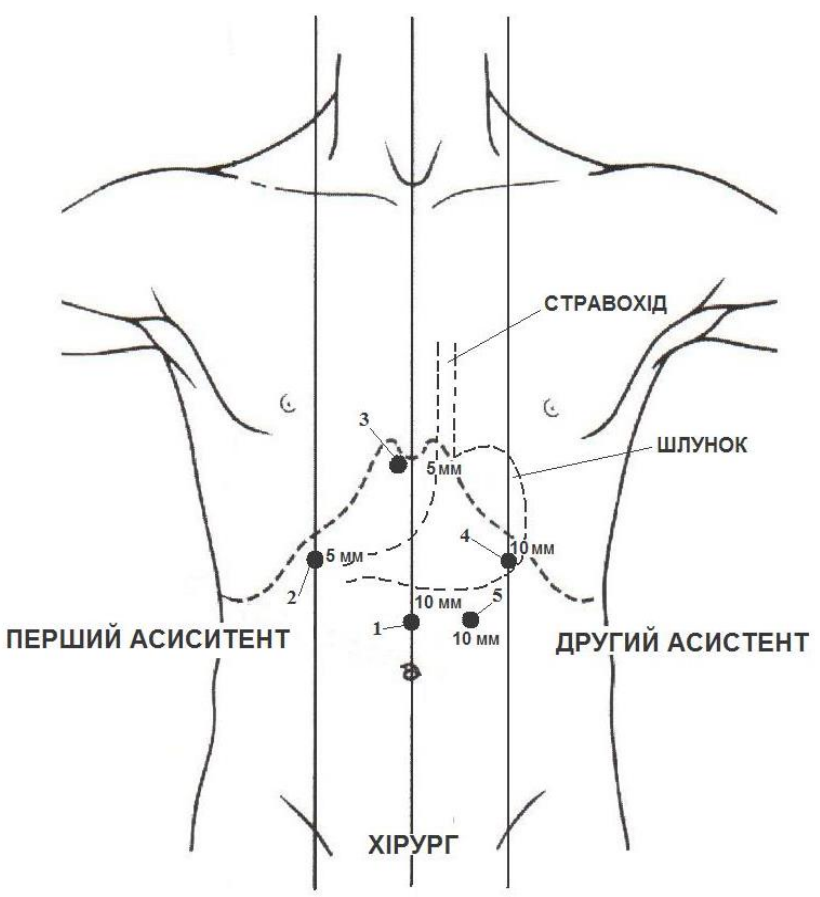

Рис. 5. Схема розміщення портів для виконання холецистектомії і фундоплікації за Тупе: 1 - 10 мм порт для лапароскопа, 2 - 5 мм порт для ретрактора, 3 - 10 мм порт для основного інструмента хірурга та затискача для холангіографії, 4 - 5 мм порт для додаткового інструмента хірурга, 5 - 5-10 мм порт для додаткового інструмента асистента. Холецистектомію виконують як завершальний етап. Холецистектомія - другий етап операції. 


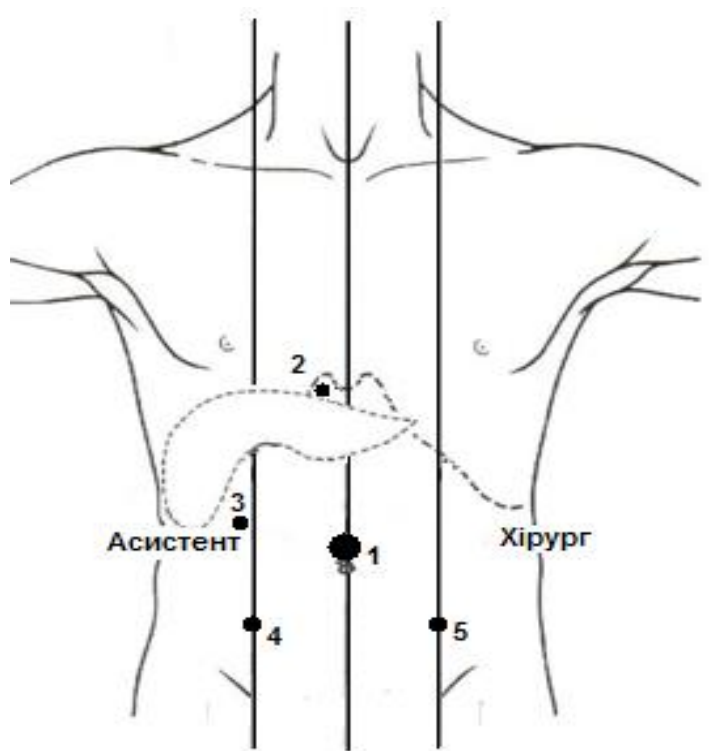

Рис. 6. Схема розміщення портів для виконання холецистектомії та алогерніопластики пахових гриж (з можливістю виконання двосторонньої пластики): 1 - 10 мм порт для лапароскопа, 2 - 10 мм порт для основного інструмента хірурга та затискача для холангіографії, 3 5 мм порт для додаткового інструмента хірурга, 4 - 5-10 мм порт для додаткового інструмента асистента/хірурга, 5 - 5 мм порт для інструмента хірурга. Холецистектомію виконують як завершальний етап. візуалізацію, використовуючи принципи вищевказані, що прямо призводить до збільшення точності й ефективності рухів інструментами, виключає рухи «наосліп», та не вимагає постійного «заглядання» та «пірнання», ергономічне розташування інструментів дозволяє досягти найвищої точності рухів у зоні хірургічної роботи при зручному положенні для хірурга, виключає паразитні рухи, нейтралізує супротив м'язово-апоневротичного апарату пацієнта, що виключає можливість ушкодження органів ОчП інструментами, і знову ж зменшує фрізичне навантаження на хірурга.

На даному етапі розвитку техніки виконання симультанних операційних втручань при поєднанні ЖКХ із грижею СОД, з паховою грижею чи холедохолітіазі, об'єктивні відчуття хірургів вказують на суттєво меншу втому після виконання даних операції, включаючи дні, коли таких операцій декілька (2-3), що підкріплюється даними, отриманими після обробки статистики тестів на фрізичну та психоемоційну втому (тест Кітаока та вимір відносної м'язової сили).

Статистика ясно вказує на відсутність відмінностей у суб'єктивних відчуттях та об'єктивних показниках втоми між одноетапними операціями та симультанними, які виконані за допомогою представленої нами методики.

Таблиця 2. Види ускладнень під час виконання операцій

\begin{tabular}{l|c|c|c}
\hline \multicolumn{1}{c|}{ Вид ускладнень } & 2009-2012 рр., n (\%) & 2013-2015 рр., n (\%) & 2016-2019 pp., n (\%) \\
\hline Внутрішньочеревна кровотеча & $13(7,6)$ & $4(2,5)$ & $2(1,7)$ \\
\hline Ушкодження органів ОЧП & $2(1,1)$ & $0(0)$ & $0(0)$ \\
\hline Диспозиція кліпси & $6(3,4)$ & $2(1,1)$ & $0(0)$ \\
\hline $\begin{array}{l}\text { Ускладнення при евакуації } \\
\text { препарату з чП }\end{array}$ & $2(1,1)$ & $2(1,1)$ & $2(1,7)$ \\
\hline
\end{tabular}

Таблиця 3. Час операції для різних нозологічних поєднань

\begin{tabular}{l|c|c}
\hline \multicolumn{1}{c|}{ Нозологічне поєднання } & Час (хв) 2009-2012 pр. & Час (хв) 2013-2019 pp. \\
\hline ЖКХ+ грижа СОД & $80-90$ & $50-55$ \\
\hline ЖКХ+ кіста печінки & $60-80$ & $40-45$ \\
\hline ЖКХ+ кіста підшлункової залози & $100-120$ & $60-80$ \\
\hline ЖХХ кіста нирок & 75 & 45 \\
\hline ЖХХ спайкова хвороба ОЧП & $60-65$ & $40-45$ \\
\hline ЖКХ+ пахова грижа & 100 & $55-65$ \\
\hline ЖКХ+ двобічна пахова грижа & 130 & $70-85$ \\
\hline
\end{tabular}

Таблиця 4. Аналіз зміни ефективності лікування

\begin{tabular}{l|c|c|c}
\hline \multicolumn{1}{c|}{ Критерії } & $2009-2012$ рp. & $2013-2015$ рр. & $2016-2019$ рр. \\
\hline Тривалість доопераційного обстеження & 1,5 діб & 1.2 діб & 1 доба \\
\hline Тривалість операції & 95 хв (+-15 хв) & 80хв (+-10 хв) & 60 хв(+-10 хв) \\
\hline Кількість інтраопераційних ускладнень & $11(6,3 \%)$ & $4(3,3 \%)$ & $4(2,4)$ \\
\hline Кількість ліжко-днів після операції & 4,8 & 3,5 & 3 \\
\hline Інтенсивність больового синдрому & незначна & незначна & незначна \\
\hline Частота ранніх післяопераційних ускладнень & $5,6 \%$ & $3,2 \%$ & $2,4 \%$ \\
\hline
\end{tabular}


Таблиця 5. Втома за результатами усереднення даних тесту Кітаока та вимірювання відносної м'язової сили у хірургів після операції

\begin{tabular}{|c|c|c|}
\hline Нозологічне поєднання & Ступінь втоми (ст.) 2009-2012 рр. & Ступінь втоми (ст.) 2013-2019 рр. \\
\hline ЖКХ+ грижа СОД & III-IV & $0-11$ \\
\hline ЖКХ+ кіста печінки & $\mathrm{I}-\mathrm{II}$ & $0-1$ \\
\hline ЖКХ+ кіста підшлункової залози & III-IV & II-III \\
\hline ЖКХ+ кіста нирок & II-IV & $0-1$ \\
\hline ЖКХ+ спайкова хвороба ОЧП & $\mathrm{I}-\mathrm{II}$ & $0-1$ \\
\hline ЖКХ+ пахова грижа & II-IV & $0-1$ \\
\hline ЖКХ+ двобічна пахова грижа & III-IV & $|-| \mid$ \\
\hline
\end{tabular}

\section{ВИСНОВкИ}

1. Поєднані хірургічні патології вимагають виконання симультанних операційних втручань, що веде до збільшення ефективності та якості лікування, не підвищуючи рівня операційних та післяопераційних ускладнень, знижуючи анестезіологічні ризики порівняно з двоетапним лікуванням

2. Використання техніки, яку ми розробили, виключно позитивно впливає на час операції шляхом забезпечення максимальної ергономіки та візуалі- зації, що, у свою чергу, веде до зниження психоемоційцної та фрізичної втоми хірургів та збільшення якості хірургічної роботи.

3. Рівень фрізичної та емоційної втоми прямо впливає на якість виконання операції, а також на проведення наступних операційних втручань, що відображається у статистичних даних рівня ускладнень та часу операцій, які суттєво знижуються після того, як ми впровадили техніку виконання симультанних операцій.

\section{СПИСОК ЛІТЕРАТУРИ}

1. Comparison of comorbidity scores in predicting surgical outcomes / H. B. Mehta, F. Dimou, D. Adhikari [et al.] // Medical Care. - 2016. - Vol. 54 (2). - P. 180-187. - Access mode : https://doi.org/10.1097/MLR.0000000000000465

2. Comparison of Charlson comorbidity index and Kaplan-Feinstein index in patients with stage I lung cancer after surgical resection / C. Y. Wang, Y. S. Lin, C. Tzao [et al.] // European Journal of Cardio-thoracic Surgery: Official Journal of the European Association for Cardio-thoracic Surgery. - 2007. - Vol. 32 (6). - P. 877-881. - Access mode : https://doi.org/10.1016/j.ejcts.2007.09.008.

3. Kyoko Imamura. Does comorbidity affect the outcome of surgery / Kyoko Imamura, Nick Black // International Journal for Quality in Health Care. - 1998. - Vol. 10, No. 2. - P. 113-123. Health Services Research Unit, Department of Public Health and Policy, London School of Hygiene and Tropical Medicine, London, UK

4. Severity of acute cholecystitis and risk of iatrogenic bile duct injury during cholecystectomy, a population-based case-control study / B. Törnqvist, A. Waage, Z. Zheng [et al.] // World Journal of Surgery. - 2016. - Vol. 40 (5). - P. 10601067. - Access mode : https://doi.org/10.1007/s00268015-3365-15. Surgical treatment of patients with acute cholecystitis: Tokyo Guidelines / Y. Yamashita, T. Takada, Y. Kawarada [et al.] // J. Hepatobiliary Pancreat. Surg. - 2007. - Vol. 14, No. 1. - P. 91-97.

6. Лапароскопічна холецистектомія в умовах гострого холециститу / М. Ю. Ничитайло, А. В. Скумс, О. М. Литвиненко [та ін.] // Шпитальна хірургія. - 2004. № 3. - C. 16-18.

7. Peter A. Acute cholecystitis and biliary colic / A. Peter, D. Steel, E. Barry Brenner // Emedicine. Medscape. 2017. Article 1950020.

8. Demehri F. R. Evidence-based management of common gallstone-related emergencies / F. R. Demehri,
H. B. Alam // Journal of Intensive Care Medicine. - 2016. - Vol. 31 (1). - P. 3-13. - Access mode : https://doi. org/10.1177/0885066614554192.

9. Gerald R. Concurrent surgery: Defining and implementing a safe practice / R. Gerald, Jr. Williams // Orthopedics Today. - 2016.

10. Joice P. Ergonomic evaluation of laparoscopic bowel suturing / P. Joice, G. B. Hanna, A. Cuschieri // American Journal of Surgery. - 1998. - Vol. 176 (4). P. 373-378. - Access mode : https://doi.org/10.1016/s00029610(98)00202-5.

12. A survey of static and dynamic work postures of operating room staff / I. J. Kant, L. C. de Jong, M. van Rijssen-Moll, P. J. Borm // International Archives of Occupational and Environmental Health. - 1992. - Vol. 63 (6). - P. 423-428. - Access mode : https://doi.org/10.1007/ BF00386939 13. Kilbom A. Measurement and assessment of dynamic work. In: Wilson EC Jr, editor. Evaluation of human work: A practical ergonomics methodology. London: Taylor and Francis; pp. 641-661.

14. Supe A. N. Ergonomics in laparoscopic surgery / A. N. Supe, G. V. Kulkarni, P. A. Supe // Journal of Minimal Access Surgery. - 2010. - Vol. 6 (2). - P. 31-36. - Access mode : https://doi.org/10.4103/0972-9941.65161.

15. Direction of gaze and comfort: discovering the relation for the ergonomic optimization of visual tasks / M. Menozzi, A. von Buol, H. Krueger, C. Miège // Ophthalmic \& Physiological Optics: The Journal of the British College of Ophthalmic Opticians (Optometrists). - 1994. - Vol. 14 (4). - P. 393-399.

16. Leopold S. S. Editorial: Overlapping surgery - honoring our patients' preferences / S. S. Leopold // Clinical Orthopaedics and Related Research. - 2018. - Vol. 476 (6). P. 1133-1134. - Access mode : https://doi.org/10.1097/01. blo.0000533622.11263. 
17. Manasnayakorn S. Ergonomic assessment of optimum operating table height for hand-assisted laparoscopic surgery / S. Manasnayakorn, A. Cuschieri, G. B. Hanna // Surgical Endoscopy. - 2009. - Vol. 23 (4). - P. 783-789. Access mode : https://doi.org/10.1007/s00464-008-0068-9.

\section{REFERENCES}

1. Mehta HB, Dimou F, Adhikari D, Tamirisa NP, Sieloff E, Williams TP, Kuo YF, Riall TS. Comparison of comorbidity scores in predicting surgical outcomes. Med Care. 2016;54(2): 180-7. Available from: doi:10.1097/ MLR.0000000000000465. PMID: 26595225; PMCID: PMC4713334.

2. Wang $\mathrm{CY}$, Lin $\mathrm{YS}$, Tzao $\mathrm{C}$, Lee $\mathrm{HC}$, Huang $\mathrm{MH}$, Hsu WH, Hsu HS. Comparison of Charlson comorbidity index and Kaplan-Feinstein index in patients with stage I lung cancer after surgical resection. Eur J Cardiothorac Surg. 2007;32(6): 877-81. Available from: DOI: 10.1016/j. ejcts.2007.09.008. Epub 2007 Oct 17. PMID: 17920921.

3. Imamura K, Black N. Does comorbidity affect the outcome of surgery? Total hip replacement in the UK and Japan. Int J Qual Health Care. 1998;10(2): 113-23. Available from: DOI: 10.1093/intqhc/10.2.113. PMID: 9690884.

4. Törnqvist $B$, Waage $A$, Zheng Z, Ye W, Nilsson $M$. Severity of acute cholecystitis and risk of iatrogenic bile duct injury during cholecystectomy, a population-based casecontrol study. World J Surg. 2016;40(5): 1060-7. Available from: DOI: 10.1007/s00268-015-3365-1. PMID: 26669783.

6. Nichitaylo MYu, Skums AV, Litvinenko OM. [Laparoscopic cholecystectomy in acute cholecystitis]. Shpyt khirur. 2004;3: 6-18. Ukrainian.

7. Peter A, Steel D, Barry E. Brenner. Acute cholecystitis and biliary colic. Emed Medscape. 2017. Art. 1950020.

8. Demehri FR, Alam HB. Evidence-based management of common gallstone-related emergencies. J Intensive Care Med. 2016;31(1): 3-13. Available from: DOI: 10.1177/0885066614554192. Epub 2014 Oct 15. PMID: 25320159.

9. Gerald R, Williams Jr. Concurrent surgery: Defining and implementing a safe practice. Orthoped. 2016;53(2): 5-11

10. Joice P, Hanna GB, Cuschieri A. Ergonomic evaluation of laparoscopic bowel suturing. Am J Surg.
18. Advanced ergonomics in laparoscopic surgery / Kostas Gianikellis, Andreas Skiadopoulos, Rafael Gutiérrez Horrillo [et al.] // Recent Advances in Laparoscopic Surgery. Open access peer-reviewed chapter. - 2019. DOI: 10.5772/ intechopen.84233.

1998;176(4): 373-8. Available from: DOI: 10.1016/s00029610(98)00202-5. PMID: 9817259.

11. Catanzarite T, Tan-Kim J, Whitcomb EL, Menefee S. Ergonomics in surgery: A Review. Female Pelvic Med Reconstr Surg. 2018;24(1): 1-12. Available from: DOI: 10.1097/SPV.0000000000000456. PMID: 28914699.

12. Kant IJ, de Jong LC, van Rijssen-Moll M, Borm PJ. A survey of static and dynamic work postures of operating room staff. Int Arch Occup Environ Health. 1992;63(6): 423-8. Available from: DOI: 10.1007/BF00386939. PMID: 1544692.

13. Kilbom A, Wilson EC Jr. Measurement and assessment of dynamic work. Evaluation of human work: A practical ergonomics methodology. London: Taylor and Francis; 1990; 641-61.

14. Supe AN, Kulkarni GV, Supe PA. Ergonomics in laparoscopic surgery. J Minim Access Surg. 2010;6(2): 316. Available from: DOI: 10.4103/0972-9941.65161. PMID: 20814508; PMCID: PMC2924545.

15. Menozzi $M$, von Buol $A$, Krueger $H$, Miège $C$. Direction of gaze and comfort: discovering the relation for the ergonomic optimization of visual tasks. Ophthalmic Physiol Opt. 1994;14(4): 393-9. PMID: 7845698.

16. Leopold SS. Editorial: Overlapping surgery honoring our patients' preferences. Clin Orthop Relat Res. 2018;476(6): 1133-4. Available from: DOI: 10.1097/01. blo.0000533622.11263.d1.

17. Manasnayakorn S, Cuschieri A, Hanna GB. Ergonomic assessment of optimum operating table height for hand-assisted laparoscopic surgery. Surg Endosc. 2009;23(4): 783-9. Available from: DOI: 10.1007/s00464008-0068-9. Epub 2008 Jul 16. PMID: 18629584

18. Gianikellis K, Skiadopoulos A, Horrillo RG, Rodal M, Sánchez-Margallo JA. Advanced ergonomics in laparoscopic surgery. Recent Advances in Laparoscopic Surgery. Opn Acc J. 2019. DOI: 10.5772/intechopen.84233. 